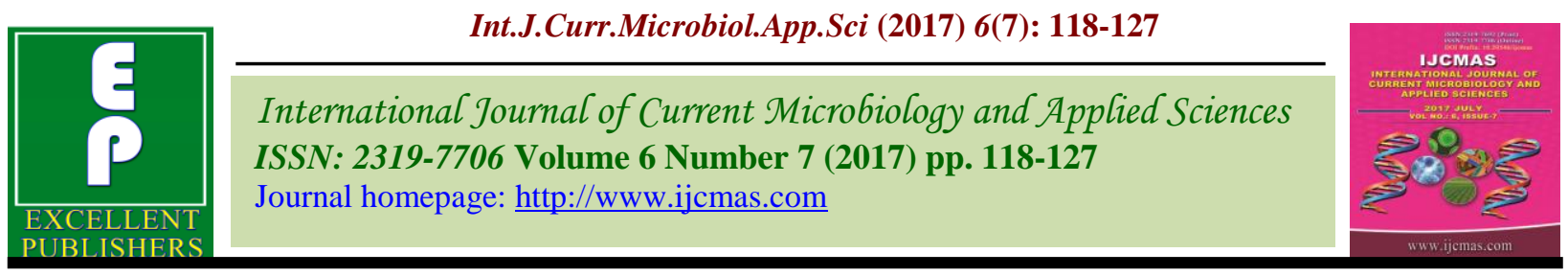

Original Research Article

https://doi.org/10.20546/ijcmas.2017.607.014

\title{
Influence of Packaging Materials on Quality of Banana Burfi during Storage
}

\author{
Venkata Satish Kuchi ${ }^{*}$, J. Kabir ${ }^{2}$, F.K. Bouri ${ }^{3}$, Rajesh Gupta ${ }^{4}$ and R.S. Dhua ${ }^{2}$ \\ ${ }^{1}$ Department of Postharvest Technology, College of Horticulture, Dr. YSRHU, \\ Anantharajupeta, Andhra Pradesh-516105, India \\ ${ }^{2}$ Department of Postharvest Technology, ${ }^{3}$ Department of Fruits and Orchard Management, \\ BCKV, Nadia, West Bengal 741252, India \\ ${ }^{4}$ Scientist, Krishi Vigyan Kendra, RVSKVV, Gwalior, Madhya Pradesh-458001, India \\ *Corresponding author
}

\begin{tabular}{|l|}
\hline K e y w o r d s \\
Ambient \\
condition, Burfi, \\
Low temperature, \\
Microbial load, \\
Packaging \\
materials. \\
\hline Article Info \\
\hline $\begin{array}{l}\text { Accepted: } \\
\text { 04 June } 2017 \\
\text { Available Online: } \\
\text { 10 July } 2017\end{array}$ \\
\hline
\end{tabular}

A B S T R A C T

The present study was carried out in the department of Postharvest Technology of Horticultural Crops, Bidhan Chandra Krishi Viswavidyalaya Mohanpur, Nadia, West Bengal during 2012-2015. Preparation of banana burfi was standardized in the laboratory by varying proportions of milk, sugar and banana pulp. It was found that $15 \%$ banana pulp $+30 \%$ sugar $+55 \%$ milk preferred by the taste panel constituted in the Faculty of Horticulture. Burfi was packed in different packaging materials i.e., Aluminium foil $\left(\mathrm{P}_{1}\right)$, butter paper $\left(\mathrm{P}_{2}\right)$ and polyethylene film $\left(\mathrm{P}_{3}\right)$ and stored in ambient conditions $\left(29 \pm 3{ }^{\circ} \mathrm{C}\right.$ and $68-81 \%$ Relative Humidity $(\mathrm{RH}))$ i.e., $\mathrm{T}_{1}$ and low temperature conditions $\left(5 \pm 1{ }^{\circ} \mathrm{C}\right.$ and $85-$ $90 \% \mathrm{RH})$ i.e., $\mathrm{T}_{2}$. Burfi packed in aluminium foil at low temperature $\left(\mathrm{T}_{2} \mathrm{P}_{1}\right)$ recorded higher score for all sensory parameters (colour: 8.1; flavour: 8.5 ; texture: 8.5 and overall acceptability: 8.3) followed by $\mathrm{T}_{2} \mathrm{P}_{3}$ (Low temperature with polyethylene film) and $\mathrm{T}_{2} \mathrm{P}_{2}$ (Low temperature with butter paper). The influence of packaging materials and storage conditions on microbial count revealed that total bacterial count and yeast and mould count were least in $\mathrm{T}_{2} \mathrm{P}_{1}$ (Low temperature + Aluminium foil) followed by $\mathrm{T}_{2} \mathrm{P}_{3}$ (Low temperature + polyethylene) and $\mathrm{T}_{2} \mathrm{P}_{1}$ (Low temperature + butter paper) on $5^{\text {th }}$ day of storage. Burfi samples stored at ambient condition irrespective of packaging material deteriorated faster due to high microbial count and not available after 5 days of storage. Burfi samples packed in aluminium foil retained moisture and could be stored for 15 days at low temperature with low microbial load and high consumer acceptability.

\section{Introduction}

Banana is one of the oldest fruits known to mankind. It is one of the widely grown and consumed fruits due to their distinct aroma and taste, in all parts of the world. It is highly nutritive and every part of the plant is useful. For these reasons it is often referred as 'Apple of Paradise' and 'Tree of paradise'. It is a good source of vitamin $\mathrm{A}, \mathrm{C}$ and $\mathrm{B}_{2}$. Fruits are rich source of minerals like magnesium, sodium, potassium, phosphorous, calcium and iron. The ripe fruits are delicious and are used for table purpose. Many products are made from banana such as banana chips, fig, soft drink, flour and jam. Banana flour is prepared from unripe fruits and banana powder from ripe fruits.

India is the largest producer of banana in the world. In West Bengal, banana is cultivated in an area of 45,500 ha with a production of 1.09 
million tonnes for the year 2013-14 (Anonymous, 2015). Moreover, with increasing population and urbanization leading to conversion of agricultural land in to industrial areas it is hardly possible to make an increase in area under cultivation. Instead, if we minimize the post-harvest losses, automatically there will be increase in production. However, this high production will have significance only when it reaches consumers in good condition.

Faulty handling practices coupled with underdeveloped and exploitive marketing systems results in postharvest losses to the extent of about $30 \%$ and value deterioration, leaving little quality surpluses for export and processing (Anonymous, 2002).

In Nadia district of West Bengal most of the banana produced is consumed in fresh form. Thus processing of banana into value added products will reduce post-harvest losses and add value to it. People in this region are fond of sweets. Innovative products like banana burfi will gain prominence in this region. The shelf life of burfi can be further increased by using suitable packing material. It will also help small scale industries and provide employment to rural youth and women. Therefore, keeping these points in view a plan of research programme on "Influence of packaging materials on quality of burfi during storage" was undertaken.

\section{Materials and Methods}

The present study was carried out in the department of Postharvest Technology of Horticultural Crops, Bidhan Chandra Krishi Viswavidyalaya Mohanpur, Nadia, West Bengal during 2012-2015. Preparation of banana burfi was standardized in the laboratory by varying proportions of milk, sugar and banana pulp. It was found that 15\% banana pulp+ $30 \%$ sugar $+55 \%$ milk preferred by the taste panel constituted in the Faculty of Horticulture.

\section{Procurement of banana fruits}

Banana fruits cultivar 'Martaman' were procured from the farm maintained by AICRP on Tropical fruits, Mandoli, Nadia district. Hands were ripened at room temperature. Healthy, unblemished fruits were selected for the preparation of burfi. Peeled fruits were washed and cleaned, and the pulp was extracted manually. It was homogenized in a deluxe pulper (mixer) machine to obtain fine pulp.

\section{Banana burfi preparation}

Banana burfi was prepared as per the procedure laid down by Sachdeva and Rajorhia (1982), with slight modification. Buffalo milk standardized to $6 \%$ fat and $15 \%$ total solids was concentrated in a stainless steel pan by open pan boiling with continuous stirring and scraping until a semi-solid mass of paste-like consistency was obtained. Sugar @ 30\% of khoa was added to sweeten the product. When the product showed a tendency to form compact mass, the temperature was lowered to $88-90{ }^{\circ} \mathrm{C}$ and selected levels of banana pulp (15\%) was added. Finally, this mixture was heated on a low fire with gentle stirring till the desired consistency of banana burfi was obtained. Just before the finish point potassium sorbate @ 0.2\% was added which acts as preservative. It was then spread uniformly in a tray with ghee and allowed to cool. After setting, banana burfi was cut into blocks of $25 \times 25 \times 25 \mathrm{~mm}$. Later, burfi was packed in different packing materials (Figure 3 ) and studied for quality attributes under ambient conditions $\left(29 \pm 3{ }^{\circ} \mathrm{C}\right.$ and $68-81 \%$ $\mathrm{RH})$ and low temperature conditions $\left(5 \pm 1{ }^{\circ} \mathrm{C}\right.$ and $85-90 \% \mathrm{RH})$. The details of treatments were presented in table 1 . 


\section{Details of observations}

Burfi packed and stored in ambient and low temperature conditions were studied for quality parameters such as moisture content, microbial count and sensory analysis.

\section{Sensory analysis}

A total of 15 male and female panellists were selected and trained for scoring. Each panellist was first briefed with the important sensory evaluation conceptual knowledge. Each panellist received and evaluated the same amount of duplicate coded sample chips in a controlled sensory evaluation laboratory with separate boxes for each panellist. The samples were evaluated on the basis of their texture, flavour, colour and overall acceptability. Furthermore, all panellists given scores for the samples for each quality feature using a hedonic scoring scale of 1 to 9 on the provided evaluation sheet according to Gupta (1976) given in table 2.

\section{Moisture content}

The moisture content was determined by taking $10 \mathrm{~g}$ of sample and dried in an oven at $65 \pm 2{ }^{\circ} \mathrm{C}$ to constant weight. The moisture content in banana burfi samples was analyzed using the AOAC (2000) method.

\section{Microbial analysis}

All the samples were subjected to total plate count (TPC) for bacteria, yeast and mold count (YMC) and coliform count. The TPC was determined by surface spreading the homogenate (prepared by macerating the burfi samples in mortar and pestle) with 10-2 dilutions on plate count agar (PCA) and incubated at $37{ }^{\circ} \mathrm{C}$ for $24 \mathrm{~h}$. For mould and yeast detection, appropriate dilutions (10-2) of sample was spread on potato dextrose agar (PDA) and incubated at $25{ }^{\circ} \mathrm{C}$ for $24 \mathrm{~h}$.
Coliforms in the samples were estimated by plating appropriate dilutions $(10-2)$ on Violet Red Bile Agar (VRBA) before being incubated at $37{ }^{\circ} \mathrm{C}$ for $24 \mathrm{~h}$ (Jain et al., 2015 and Abdalla and Ahmed, 2010).

\section{Statistical design}

The data obtained from four replications were subjected to the analysis of variance by ' $F$ ' test for two factor Factorial Completely Randomized Design (Gomez and Gomez, 1984).

\section{Results and Discussion}

The treatment which performed best in experiment "Standardization of banana burfi making and quality assessment" i.e. $\mathrm{T}_{6}(15 \%$ banana pulp $+30 \%$ sugar $+55 \%$ Milk) was taken in this experiment to study the effect of packaging materials on quality of burfi under different storage conditions.

The quality of burfi standardized with $15 \%$ banana pulp $+30 \%$ sugar $+55 \%$ Milk is presented in table 3 . The colour, flavour texture and overall acceptability of the prepared burfi were recorded 8.8, 8.5, 8.5 and 8.6 respectively. The effect of storage condition on the sensory quality of burfi has been depicted in table 4 . In general it has been found that the burfi stored at $\mathrm{T}_{2}$ (Low temperature) was found superior to $T_{1}$ (Ambient condition) and colour, flavour, texture and overall acceptability of $T_{2}$ remained significantly higher (i.e. 8.0, 8.3, 8.3 and 8.2 respectively) than $\mathrm{T}_{1}(6.9,6.9,6.8$ and 6.9 respectively) on $5^{\text {th }}$ day of storage. Although sensory score for packaging with aluminium foil $\left(\mathrm{P}_{1}\right)$ was higher than that of polyethylene film $\left(\mathrm{P}_{1}\right)$, the score for colour, flavour, texture and overall acceptability of both the treatments i.e. $\mathrm{P}_{1}$ (Aluminium foil) and $\mathrm{P}_{3}$ (Polyethylene film) were at par. Interaction effect of packaging and storage 
condition on $5^{\text {th }}$ day of storage revealed that sensory score for texture was significant $(\mathrm{P} \leq 0.05)$, while colour, flavour and overall acceptability were non-significant $(\mathrm{P} \leq 0.05)$. The interaction effect of $\mathrm{T}_{2} \mathrm{P}_{1}$ (Low temperature storage and aluminium foil) recorded higher score for all sensory parameters followed by $\mathrm{T}_{2} \mathrm{P}_{3}$ (Low temperature storage and polyethylene film) and $\mathrm{T}_{2} \mathrm{P}_{2}$ (Low temperature storage and butter paper).

Sensory scores for $\mathrm{T}_{1} \mathrm{P}_{1}$ were least. Burfi samples kept at ambient conditions $\left(29 \pm 3{ }^{\circ} \mathrm{C}\right.$ and $68-81 \% \mathrm{RH})$ were not available after 5 days of storage for further evaluation.

Initial moisture content of burfi was recorded $14.81 \%$ (Table 5). On the $5^{\text {th }}$ day of storage there was a slight decrease in moisture content of burfi samples stored at ambient conditions $\left(29 \pm 3{ }^{\circ} \mathrm{C}\right.$ and $\left.68-81 \% \mathrm{RH}\right)$ and low temperature conditions $\left(5 \pm 1^{\circ} \mathrm{C}\right.$ and 85 $90 \% \mathrm{RH})$ except in treatment combination $\mathrm{T}_{2} \mathrm{P}_{1}$ (Low temperature storage and aluminium foil) where it remained the same (Table 4).

In general, at ambient condition $\left(\mathrm{T}_{1}\right)$, moisture content reduced significantly $(\mathrm{P} \leq 0.05)$ in comparison to low temperature $\left(\mathrm{T}_{2}\right)$. In butter paper package moisture content was significantly lower than $\mathrm{P}_{1}$ (Aluminium foil) and $\mathrm{P}_{3}$ (Polyethylene film) on $5^{\text {th }}$ day of storage. Although $\mathrm{P}_{1}$ (Aluminium foil) retained higher moisture content treatment $\mathrm{P}_{1}$ and $\mathrm{P}_{3}$ were at par. On $5^{\text {th }}$ day, interaction effect of temperature and package revealed that moisture content was least in $T_{1} P_{2}$ (Ambient condition and butter paper) and maximum in $\mathrm{T}_{2} \mathrm{P}_{1}$ (Low temperature storage and aluminium foil).

Regarding influence of packaging materials and storage conditions on microbial count of banana burfi on $5^{\text {th }}$ day of storage were statistically analysed (Table 5). No coliforms were detected in any of the samples. Total bacterial count and yeast and mould count significantly $(\mathrm{P}<0.05)$ higher $\quad(9.42 \quad \log 10$ $\mathrm{CFU} / \mathrm{g}$ and $8.84 \log 10 \mathrm{CFU} / \mathrm{g}$ ) in the samples stored in $\mathrm{T}_{1}$ (ambient conditions) than $\mathrm{T}_{2}$ (Low temperature conditions). However, the samples stored in $\mathrm{P}_{1}$ (Aluminium foil) were found to be containing significantly low (4.60 $\log 10 \mathrm{CFU} / \mathrm{g}$ and $2.28 \log 10 \mathrm{CFU} / \mathrm{g}$ ) total bacterial count and yeast and mould count than $\mathrm{P}_{3}$ (Polyethylene film) and $\mathrm{P}_{2}$ (butter paper). Interaction effect showed that total bacterial count and yeast and mould count were least $(2.45 \log 10 \mathrm{CFU} / \mathrm{g}$ and $1.41 \log 10$ $\mathrm{CFU} / \mathrm{g}$ ) in $\mathrm{T}_{2} \mathrm{P}_{1}$ (low temperature storage and aluminium foil) followed by $\mathrm{T}_{2} \mathrm{P}_{3}$ (Low temperature storage and polyethylene film) and $\mathrm{T}_{2} \mathrm{P}_{1}$ (Low temperature storage and butter paper). While at ambient condition $\mathrm{T}_{1} \mathrm{P}_{2}$ (Ambient condition and butter paper) and $\mathrm{T}_{1} \mathrm{P}_{3}$ total bacterial count (Figure 5) and yeast and mould count were significantly high. Highest counts ( $12.55 \log 10 \mathrm{CFU} / \mathrm{g}$ and 13.76 $\log 10 \mathrm{CFU} / \mathrm{g}$ ) for bacterial and mould and yeast were observed in $\mathrm{T}_{1} \mathrm{P}_{2}$ (Ambient condition and butter paper). As a result of high microbial count burfi kept in ambient conditions was not suitable beyond $5^{\text {th }}$ day but burfi samples kept in low temperature conditions could be stored for 15 days.

Sensory data of low temperature at 10 and 15 days of storage is shown in bar diagram (Figure 1). Colour, flavor, texture and overall acceptability of $\mathrm{T}_{2} \mathrm{P}_{1}$ (Low temperature storage and aluminium foil) was high (8.00) on $10^{\text {th }}$ day of storage followed by $\mathrm{T}_{2} \mathrm{P}_{3}$ (Low temperature storage and polyethylene film) and $\mathrm{T}_{2} \mathrm{P}_{2}$ (Low temperature storage and butter paper). On $15^{\text {th }}$ day also the trend of sensory quality was similar, only the score was less than 10 days. The sensory score of $\mathrm{T}_{2} \mathrm{P}_{2}$ (Low temperature storage and butter paper) for colour, flavor, texture and overall acceptability was appreciably low. 
Table.1 Details of the treatments

\begin{tabular}{|l|l|c|}
\hline Storage conditions & Packing materials & Treatment symbol \\
\hline Ambient conditions $\left(\mathrm{T}_{1}\right)$ & Aluminium foil $(11 \mu)\left(\mathrm{P}_{1}\right)$ & $\mathrm{T}_{1} \mathrm{P}_{1}$ \\
\cline { 2 - 3 } & Butter paper $\left(\mathrm{P}_{2}\right)$ & $\mathrm{T}_{2} \mathrm{P}_{2}$ \\
\cline { 2 - 3 } & LDPE $(100$ guage $)\left(\mathrm{P}_{3}\right)$ & $\mathrm{T}_{1} \mathrm{P}_{3}$ \\
\hline \multirow{3}{*}{ Low temperature $\left(\mathrm{T}_{2}\right)$} & Aluminium foil $(11 \mu)\left(\mathrm{P}_{1}\right)$ & $\mathrm{T}_{2} \mathrm{P}_{1}$ \\
\cline { 2 - 3 } & Butter paper $\left(\mathrm{P}_{2}\right)$ & $\mathrm{T}_{2} \mathrm{P}_{2}$ \\
\cline { 2 - 3 } & LDPE $(100$ guage $)\left(\mathrm{P}_{3}\right)$ & $\mathrm{T}_{2} \mathrm{P}_{3}$ \\
\hline
\end{tabular}

Table.2 Score acceptability for panellists

\begin{tabular}{|l|l|}
\hline Score & Acceptability \\
\hline 9 & Extremely desirable \\
\hline 8 & Very much desirable \\
\hline 7 & Moderately desirable \\
\hline 6 & Slightly desirable \\
\hline 5 & Neither desirable nor undesirable \\
\hline 4 & Slightly undesirable \\
\hline 3 & Moderately undesirable \\
\hline 2 & Very much undesirable \\
\hline 1 & Extremely undesirable \\
\hline
\end{tabular}

Table.3 Sensory quality and moisture content of fresh burfi

\begin{tabular}{|l|l|}
\hline Sensory quality & Mean score \\
\hline Colour & 8.8 \\
\hline Flavour & 8.5 \\
\hline Texture & 8.5 \\
\hline Overall acceptability & 8.6 \\
\hline Moisture content & $14.81 \%$ \\
\hline
\end{tabular}

Table.4 Effect of packaging and storage condition on sensory quality of burfi on $5^{\text {th }}$ day

\begin{tabular}{|l|c|c|c|c|}
\hline Treatments & Colour & Flavour & Texture & Overall acceptability \\
\hline $\mathbf{T}_{\mathbf{1}}$ & 6.9 & 6.9 & 6.8 & 6.9 \\
\hline $\mathbf{T}_{\mathbf{2}}$ & 8.0 & 8.3 & 8.3 & 8.2 \\
\hline SEm & 0.13 & 0.09 & 0.05 & 0.06 \\
\hline $\mathbf{C D}_{\mathbf{0 . 0 5}}$ & 0.40 & 0.25 & 0.14 & 0.19 \\
\hline $\mathbf{P}_{\mathbf{1}}$ & 7.5 & 7.9 & 7.8 & 7.8 \\
\hline $\mathbf{P}_{\mathbf{2}}$ & 7.3 & 7.3 & 7.1 & 7.2 \\
\hline $\mathbf{P}_{\mathbf{3}}$ & 7.5 & 7.7 & 7.7 & 7.6 \\
\hline $\mathbf{S E m}$ & 0.16 & 0.10 & 0.06 & 0.08 \\
\hline $\mathbf{C D}_{\mathbf{0 . 0 5}}$ & $\mathrm{NS}$ & 0.31 & 0.17 & 0.23 \\
\hline $\mathbf{T}_{\mathbf{1}} \mathbf{P}_{\mathbf{1}}$ & 7.0 & 7.3 & 7.2 & 7.2 \\
\hline $\mathbf{T}_{\mathbf{1}} \mathbf{P}_{\mathbf{2}}$ & 6.7 & 6.4 & 6.2 & 6.4 \\
\hline $\mathbf{T}_{\mathbf{1}} \mathbf{P}_{\mathbf{3}}$ & 6.9 & 7.1 & 7.1 & 7.0 \\
\hline $\mathbf{T}_{\mathbf{2}} \mathbf{P}_{\mathbf{1}}$ & 8.1 & 8.5 & 8.5 & 8.3 \\
\hline $\mathbf{T}_{\mathbf{2}} \mathbf{P}_{\mathbf{2}}$ & 8.0 & 8.1 & 8.1 & 8.1 \\
\hline $\mathbf{T}_{\mathbf{2}} \mathbf{P}_{\mathbf{3}}$ & 8.1 & 8.3 & 8.3 & 8.2 \\
\hline $\mathbf{S E m}_{\mathbf{C} E \mathbf{m}}$ & 0.23 & 0.15 & 0.08 & 0.11 \\
\hline $\mathbf{C D}_{\mathbf{0 . 0 5}}$ & $\mathrm{NS}$ & $\mathrm{NS}$ & 0.24 & $\mathrm{NS}$ \\
\hline
\end{tabular}

$\mathrm{T}_{1}$ : Ambient temperature, $\mathrm{T}_{2}$ : Low temperature storage

$\mathrm{P}_{1}$ : Aluminium Foil, $\mathrm{P}_{2}$ : Butter paper, $\mathrm{P}_{3}$ : Polyethylene Film 
Table.5 Effect of packaging and storage condition on moisture content (\%) and Microbial count of burfi on $5^{\text {th }}$ day of storage

\begin{tabular}{|l|c|c|c|}
\hline Treatments & $\begin{array}{c}\text { Moisture } \\
\text { content }(\mathbf{\%})\end{array}$ & $\begin{array}{c}\text { Total bacterial count } \\
\left(\log _{\mathbf{1 0}} \mathbf{C F U} / \mathbf{g}\right)\end{array}$ & $\begin{array}{c}\text { Total mould and yeast } \\
\text { count }\left(\log _{\mathbf{1 0}} \mathbf{C F U} / \mathbf{g}\right)\end{array}$ \\
\hline $\mathbf{T}_{\mathbf{1}}$ & 13.88 & 9.42 & 8.84 \\
\hline $\mathbf{T}_{\mathbf{2}}$ & 14.77 & 3.18 & 3.46 \\
\hline $\mathbf{S E m}$ & 0.06 & 0.17 & 0.06 \\
\hline $\mathbf{C D}_{\mathbf{0 . 0 5}}$ & 0.17 & 0.50 & 0.18 \\
\hline $\mathbf{P}_{\mathbf{1}}$ & 14.44 & 4.60 & 2.28 \\
\hline $\mathbf{P}_{\mathbf{2}}$ & 14.16 & 8.35 & 9.79 \\
\hline $\mathbf{P}_{\mathbf{3}}$ & 14.38 & 5.95 & 6.38 \\
\hline $\mathbf{S E m}_{\mathbf{C}}$ & 0.07 & 0.21 & 0.07 \\
\hline $\mathbf{C D}_{\mathbf{0 . 0 5}}$ & 0.21 & 0.61 & 0.22 \\
\hline $\mathbf{T}_{\mathbf{1}} \mathbf{P}_{\mathbf{1}}$ & 14.13 & 6.75 & 3.15 \\
\hline $\mathbf{T}_{\mathbf{1}} \mathbf{P}_{\mathbf{2}}$ & 13.56 & 12.55 & 13.76 \\
\hline $\mathbf{T}_{\mathbf{1}} \mathbf{P}_{\mathbf{3}}$ & 13.96 & 8.95 & 9.63 \\
\hline $\mathbf{T}_{\mathbf{2}} \mathbf{P}_{\mathbf{1}}$ & 14.81 & 2.45 & 1.41 \\
\hline $\mathbf{T}_{\mathbf{2}} \mathbf{P}_{\mathbf{2}}$ & 14.75 & 4.15 & 5.83 \\
\hline $\mathbf{T}_{\mathbf{2}} \mathbf{P}_{\mathbf{3}}$ & 14.77 & 2.95 & 3.14 \\
\hline $\mathbf{S E m}_{\mathbf{C} \mathbf{D}_{\mathbf{0 . 0 5}}}$ & 0.10 & 0.29 & 0.11 \\
\hline
\end{tabular}

$\mathrm{T}_{1}$ : Ambient temperature $\mathrm{T}_{2}$ : Low temperature storage, $\mathrm{P}_{1}$ : Aluminium Foil, $\mathrm{P}_{2}$ : Butter paper, $\mathrm{P}_{3}$ : Polyethylene Film CFU: Colony forming units

Fig.1 Effect of packaging on sensory quality of burfi on $10^{\text {th }}$ and $15^{\text {th }}$ day of storage at low temperature

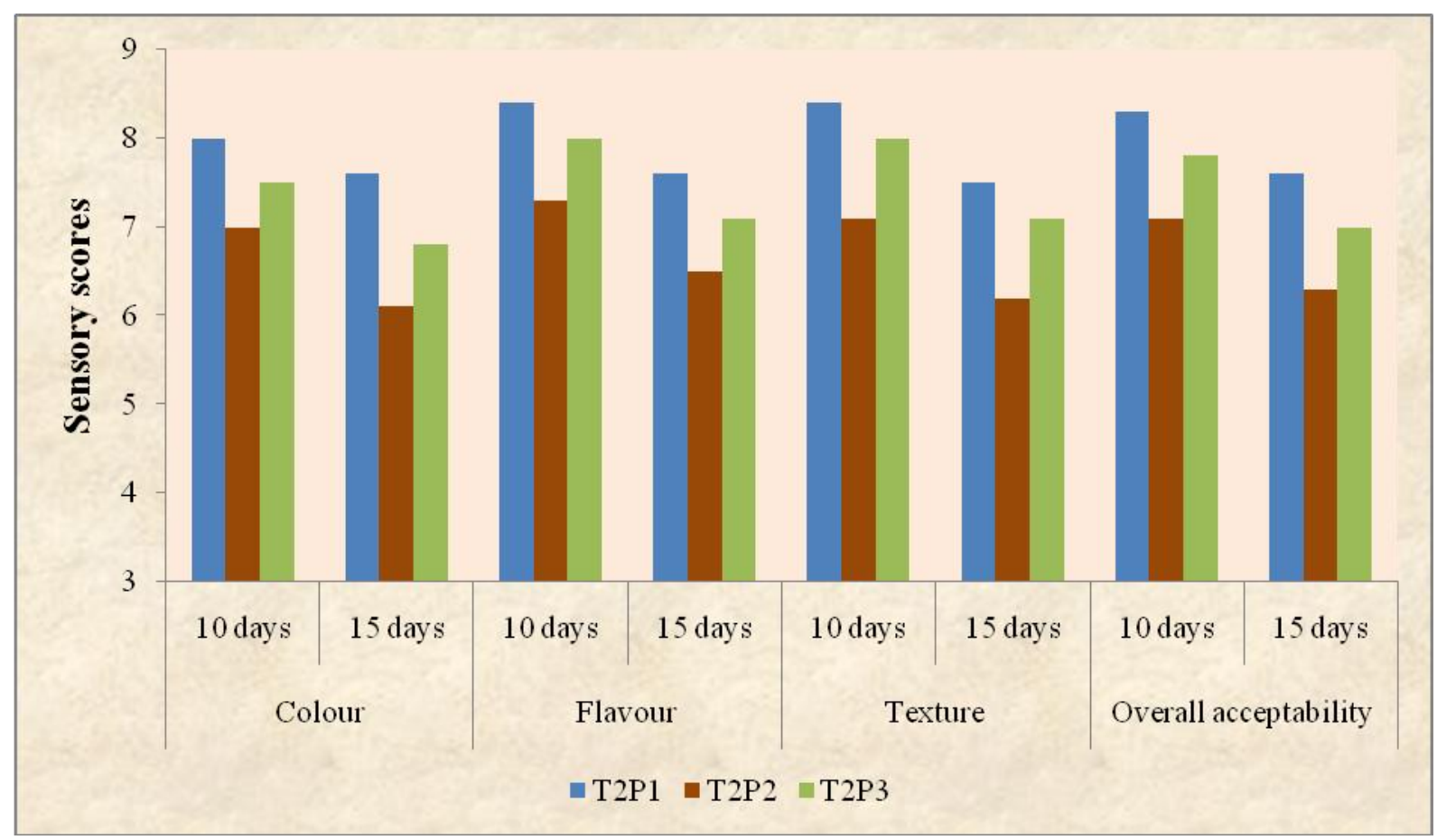


Fig.2 Effect of packaging on moisture content (\%) of burfi on $10^{\text {th }}$ and $15^{\text {th }}$ day at low temperature storage

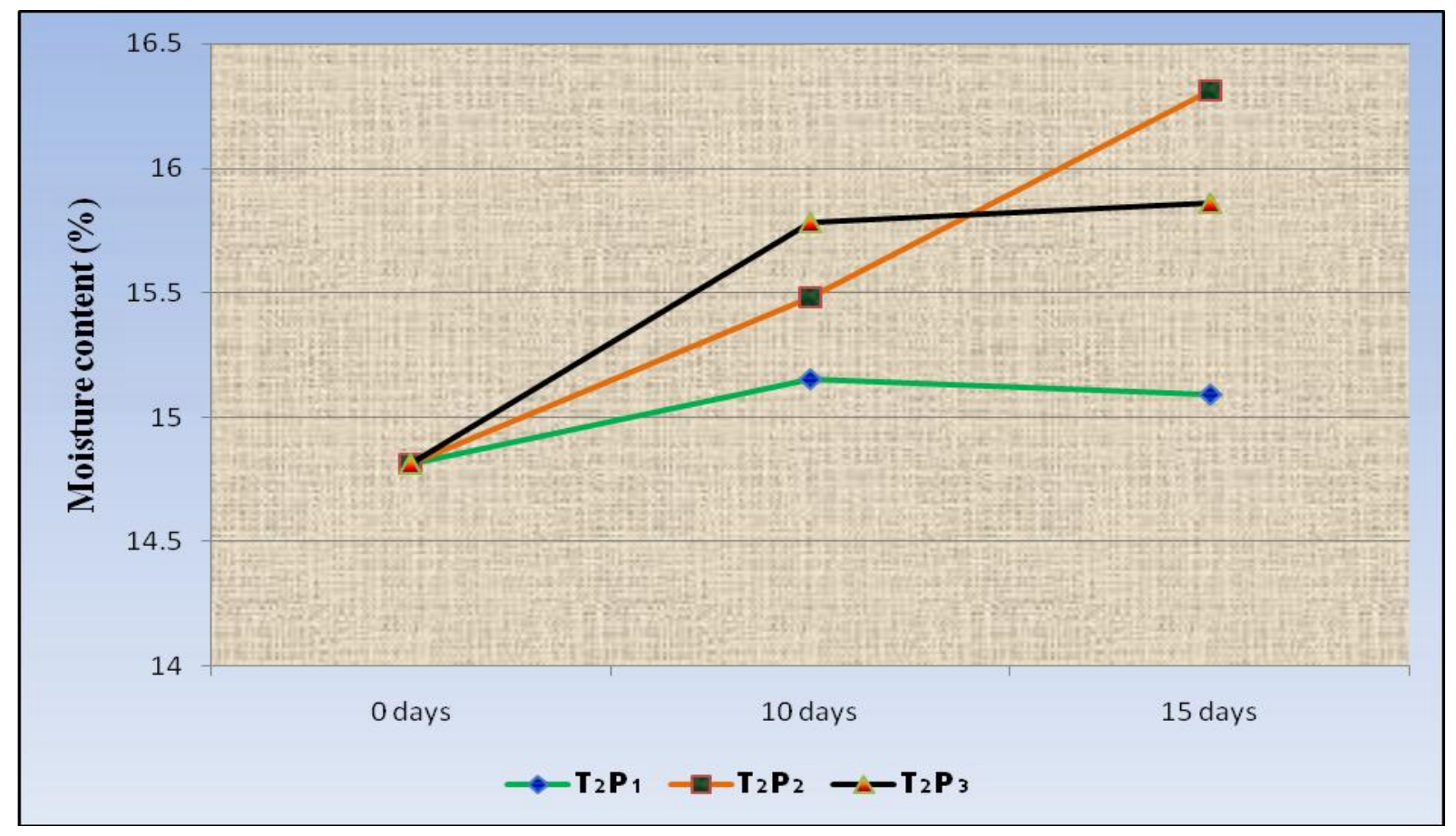

Fig.3 Packaging of burfi

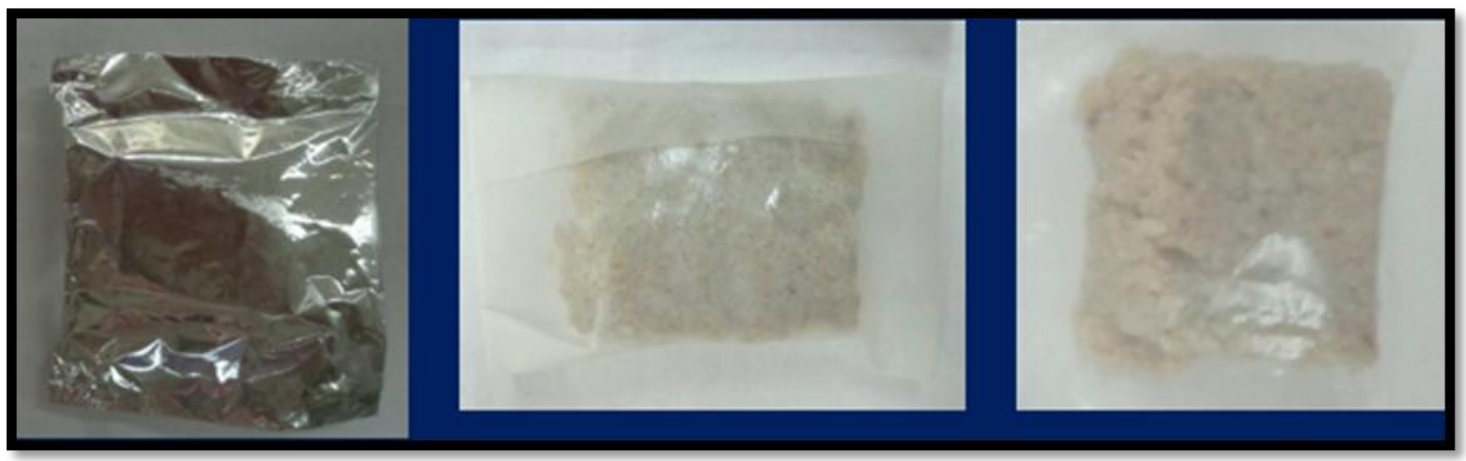

Fig.4 Burfi samples after 15 days of storage under low temperature

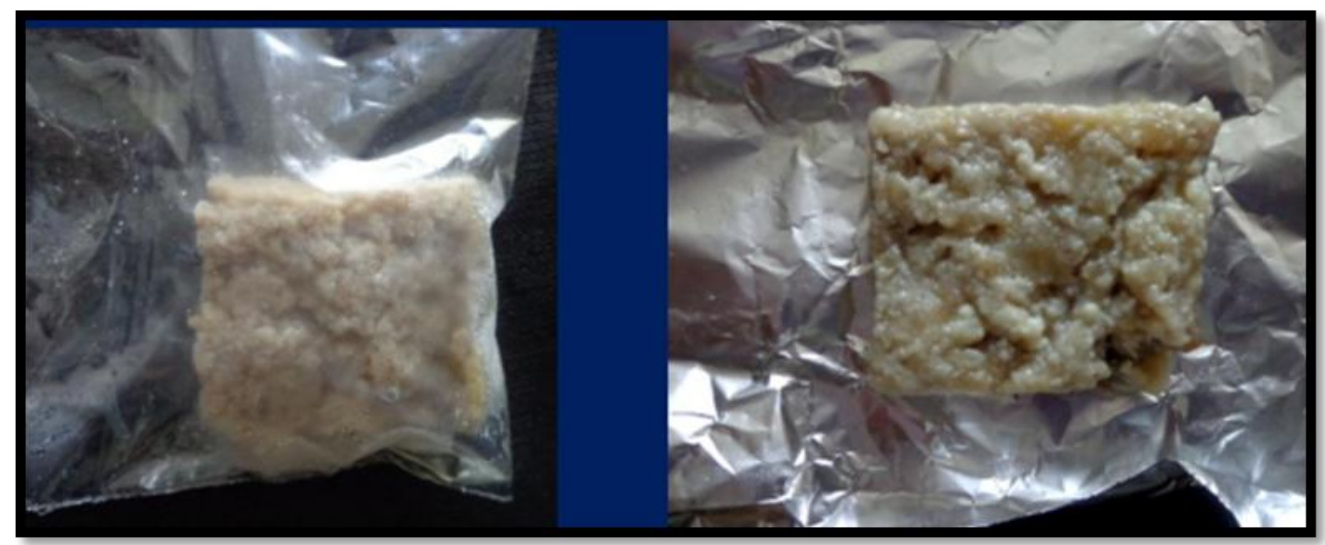


Fig.5 Total plate count of bacteria on $5^{\text {th }}$ day of storage

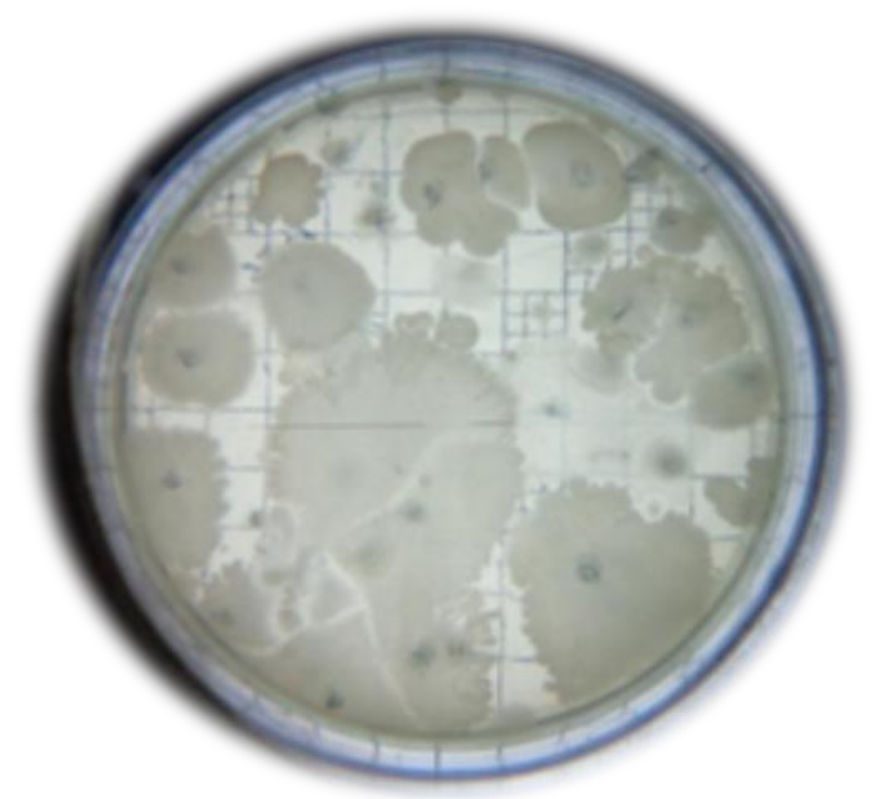

Moisture content at low temperature of $\mathrm{T}_{2} \mathrm{P}_{1}$ (Low temperature storage and aluminium foil), $\mathrm{T}_{2} \mathrm{P}_{2}$ (Low temperature storage and butter paper) and $\mathrm{T}_{2} \mathrm{P}_{3}$ (Low temperature storage and polyethylene film) on $10^{\text {th }}$ and $15^{\text {th }}$ day as shown in figure 2 indicated that $\mathrm{T}_{2} \mathrm{P}_{1}$ possessed least moisture both at $10^{\text {th }}$ and $15^{\text {th }}$ day followed by $\mathrm{T}_{2} \mathrm{P}_{3}$ and $\mathrm{T}_{2} \mathrm{P}_{2}$ in that increasing order.

Thus, it can be concluded that burfi samples packaged in aluminium foil could be stored for 15 days at low temperature with low microbial load while retaining moisture content with high consumer acceptability but at ambient condition for 5 days.

There is decrease in scores for sensory quality such as colour, flavour, texture and overall acceptability irrespective of the burfi packed in different packaging materials and storage conditions. The rate of decrease in sensory scores was much higher in burfi kept at ambient conditions than low temperature conditions. This might be due to loss of moisture from the product (Londhe et al.,
2012) resulting in darker burfi colour (Chawla et al., 2013). The banana burfi packaged in aluminium foil and stored at low temperature were acceptable upto 15 days as shown from superior colour, flavour, texture and overall acceptability table 4 and figure 4 . Low moisture content of $\mathrm{T}_{2} \mathrm{P}_{1}$ treatment on $15^{\text {th }}$ day was because of low water vapour transmission rate of aluminium foil when compared to other packing materials. This was the reason for superiority of burfi of $\mathrm{T}_{2} \mathrm{P}_{1}$. These findings are in confirmation with Venkatesh et al., (1984) who reported that sohan halwa packed in aluminium foil could be stored for 180 days with acceptable sensory quality. Parallel reports had been given by Bhatele (1983) on burfi; Sharma et al., (2003) and Londhe et al., (2012) while working on efficient packaging techniques on peda storage. The decrease in flavour might be attributed to slight loss in freshness, which is inherent with any food product. Similar observations were recorded by Biradar et al., (1985), Rao and Goyal (2007) and Londhe et al., (2012). 
During the storage under different temperature conditions all the burfi samples contained differential microbial counts. There was higher microbial count (total plate count (bacteria) and mould and yeast growth) in burfi stored in ambient conditions than in low temperature conditions might be due to unfavorable temperature for the microbes to enter and multiply. Similar reports were presented by Garg and Mandokhot (1987); Misra and Kuila (1988) and Sachdeva (1980). Kumar et al., (1997) in their study on the extension of shelf-life of peda did not observe increase in the microbial growth during storage in the product packaged under MAP with oxygen scavengers.

Burfi packed in aluminium foil at low temperature $\left(\mathrm{T}_{2} \mathrm{P}_{1}\right)$ recorded higher score for all sensory parameters (colour: 8.1; flavour: 8.5; texture: 8.5 and overall acceptability: 8.3). The influence of packaging materials and storage conditions on microbial count revealed that total bacterial count and yeast and mould count were least in $\mathrm{T}_{2} \mathrm{P}_{1}$ (Low temperature + Aluminium foil) (Fig. 3). Burfi samples stored at ambient condition irrespective of packaging material deteriorated faster due to high microbial count and not available after 5 days of storage. Burfi samples packed in aluminium foil retained moisture and could be stored for 15 days at low temperature with low microbial load and high consumer acceptability. In conclusion, aluminium foil packaging along with low temperature storage is best for maintaining the quality and prolonging the shelf-life of banana burfi.

\section{Acknowledgements}

Authors convey gratitude to All India Coordinated Research Project on Tropical Fruits for providing necessary quantity of Martaman banana fruits and sincere support throughout the study. Authors also thank staff of Department of Dairy Microbiology, West Bengal University of Animal and Fishery Sciences, Mohanpur, West Bengal for providing technical support and research laboratory facilities throughout the research project.

\section{References}

Abdalla, M.O.M. and Ahmed, A.N.S.Z. 2010. Evaluation of microbiological quality of sudanese fermented dairy product 'mish' during storage. Adv. J. Food Sci. Technol., 2:155-158.

Anonymous. 2002. Group Workers Meeting of AICRP on PHT of horticultural crops. Trial Data of 2000-2001 presented in Workshop held at Konkan Krishi Vidyapeeth, Dapoli from 5th to 7th March 2002.

Anonymous. 2015. Indian Horticulture Database, NHB. Aristo Printing Press, DDA Shed, Okhla Industrial Area, Phase-I, New Delhi, India, pp 34-41.

AOAC (17th Ed.). 2000. Official methods of analysis of AOAC International, Gaithersburg, MD, USA.

Bhatele, I.D. 1983. Studies on the production, packaging and preservation of burfi. Ph.D. thesis, submitted to Kurukshetra University, Kurukshetra, Chandigarh, India.

Biradar, U.S., Dev, D.K. and Ingle, U.M. 1985. Shelf-life extension of pedha by packaging. J. Food Sci., 50: 51-55.

Chawla, R., Patil, G. and Singh, A. 2013. Effect of temperature on sensory and textural attributes of functional doda burfi (Indian milk cake). J. Food Sci. Technol., 52(1): 586-591.

Garg, S.R. and Mandokhot, U.V. 1987. Survival and growth of microorganisms in burfi and peda during storage. Indian J. Dairy Sci., 40(1): 119-121.

Gomez, K.A. and Gomez, A.A. 
1984. Statistical procedures for agricultural research, (2 ${ }^{\text {nd }}$ Edn.) John Wiley and Sons, New York.

Gupta, S.A. 1976. Sensory evaluation of food. Indian Dairyman, 28(8): 293-295.

Jain, V., Rasane, P., Jha, A., Sharma, N. and Gautam, A. 2015. Effect of modified atmospheric packaging on the shelf life of Kalakand and its influence on microbial, textural, sensory and physico-chemical properties. J. Food Sci. Technol., 52(7): 4090-4101.

Kumar, R., Bandyopadhyay, P. and Punjrath, J.S. 1997. Shelf-life extension of peda using different packaging techniques. Indian J. Dairy Sci., 50(1): 40-49.

Londhe, G., Pal, D. and Raju, P. 2012. Effect of packaging techniques on shelf life of brown peda, a milk-based confection. LWT - Food Sci. Technol., 47(1): 117125.

Misra, A. K. and Kuila, R.K. 1988. Microbiological quality of burfi and sandesh. Asian J. Dairy Res., 7(1): 5155.
Rao, R.S. and Goyal, G.K. 2007. Effect of packaging and storage on the sensory quality of Kalakand. Indian J. Dairy Sci., 60(2): 77-80.

Sachdeva, S. 1980. Studies in the technology and shelf life of burfi. M.Sc. thesis, submitted to Kurukshetra University, Kurukshetra, Chandigarh, India.

Sachdeva, S. and Rajorhia, G.S. 1982. Technology and shelf life of burfi. Indian J. Dairy sci., 35(4): 513-518.

Sharma, H.K., Singhal, R.S. and Kulkarni, P.R. 2003. Effect of modified atmosphere packaging on the keeping quality of Malai peda. J. Food Sci. Technol., 40(5): 543-545.

Venkatesh, K.V.L., Dhanaraj, S., Mahadeviah, B., Ananthakrishna, S.M., Mahadeviah, M., Anandaswamy, B., Govindarajan, V.S. and Sen, D.P. 1984. Effect of packaging on quality of sohan halwa during storage. J. Food Sci. Technol., 21(3): 167-171.

\section{How to cite this article:}

Venkata Satish Kuchi, J. Kabir, F.K. Bouri, Rajesh Gupta and Dhua, R.S. 2017. Influence of Packaging Materials on Quality of Banana Burfi during Storage. Int.J.Curr.Microbiol.App.Sci. 6(7): 118-127. doi: https://doi.org/10.20546/ijcmas.2017.607.014 